\title{
Penyerapan Ion Logam Kadmium Dan Tembaga Oleh Genjer (Limnocharis flava)
}

\author{
Nurhasni \\ Program Studi Kimia FST UIN Syarif Hidayatullah Jakarta \\ hasni_1806@yahoo.com
}

\begin{abstract}
Abstrak
Telah dilakukan penelitian tentang penyerapan ion logam kadmium dan tembaga oleh genjer (limnocharis flava) dengan metode dinamis. Dari hasil penelitian didapatkan kondisi optimum penyerapan pada $\mathrm{pH} 5$, ukuran partikel $180 \mu \mathrm{m}$, dan suhu pemanasan $90^{\circ} \mathrm{C}$. Kapasitas penyerapan untuk Cd(II) adalah $17,71 \mathrm{mg}$ ion logam/g sorben, sedangkan untuk $\mathrm{Cu}(\mathrm{II})$ adalah $17,45 \mathrm{mg}$ ion logam/g sorben. Ion logam yang telah diserap dielusi dengan $\mathrm{HNO}_{3}$ dan EDTA dengan recovery 63,44-100\%. Penyerapan ion logam kadmium dan tembaga pada kondisi optimum yang diaplikasikan pada air limbah laboratorium kimia mempunyai kapasitas penyerapan masing-masing adalah 0,030 dan $0.013 \mathrm{mg}$ ion logam/ g sorben.
\end{abstract}

Kata kunci: genjer, ion logam kadmium, ion logam tembaga, air limbah

\begin{abstract}
The sorption cadmium and copper metal ions by genjer (Limnocharis flava) using dynamic method has been studied. Results obtained from optimum conditions sorption at $\mathrm{pH} 5$, particle size $180 \mu \mathrm{m}$, and temperature heating $90{ }^{\circ} \mathrm{C}$. Sorptions capacities were $\mathrm{Cd}(\mathrm{II})$ is $17.71 \mathrm{mg}$ metal ion/ $\mathrm{g}$ sorben, and $\mathrm{Cu}(\mathrm{II})$ is $17.45 \mathrm{mg}$ metal ion/ $\mathrm{g}$ sorben. Elution of metal ions was done eluted with $\mathrm{HNO}_{3}$ and EDTA the recovery 63,44-100\%. The sorption cadmium and copper metal ions at optimum conditions applied to waste water laboratory chemistry had sorptions capacities to $\mathrm{Cd}(\mathrm{II})$ is $0.030 \mathrm{mg}$ metal ion/ $\mathrm{g}$ sorben, and $\mathrm{Cu}$ (II) is $0.013 \mathrm{mg}$ metal ion/g sorben.
\end{abstract}

Keywords: genjer, cadmium, copper, waste water

\section{PENDAHULUAN}

Pencemaran atau polusi adalah suatu kondisi yang telah merubah lingkungan dari bentuk asal menjadi keadaan yang lebih buruk. Pergeseran bentuk tatanan dari bentuk asal pada kondisi yang buruk ini dapat terjadi sebagai akibat masukan dari bahan-bahan pencemar atau polutan. Bahkan polutan tersebut pada umumnya mempunyai sifat racun (toksik) yang berbahaya bagi organisme hidup. Toksisitas atau daya racun dari polutan itulah yang kemudian menjadi pemicu terjadinya pencemaran (Palar, 1994)

Polusi lingkungan oleh logam-logam berat terjadi sebagai hasil dari berbagai kegiatan seperti industri, pertanian, dan limbah perkotaan (Matheichal dan Qiming Yu, 1999). Logam berat yang berada di lingkungan dapat membahayakan makhluk hidup terutama manusia bila ikut masuk ke dalam rantai makanan. Logam berat yang memberi dampak negatif terhadap kesehatan diantaranya $\mathrm{Pb}, \mathrm{Cd}$, Se, As, Cr (Manahan, 1984). Logam berat cendrung membentuk kompleks dengan ligan organik maupun anorganik di dalam air alam. Penentuan secara langsung logam berat dengan peralatan yang tersedia kadang sulit dilakukan karena konsentrasinya yang sangat kecil (runut) dan banyaknya matriks dari media yang kompleks seperti air laut (Michael dan Pierre, 1994).

Pengolahan air limbah dapat dilakukan dengan penyerapan bahan pencemar umumnya menggunakan penyerap sintesis diantaranya, resin (Michael dan Pierre, 1994), karbon aktif (Giequel et al., 1997), dan silika gel (Lessi et al., 1996), tetapi harganya relatif mahal. Hal tersebut telah mendorong beberapa peneliti untuk mencari penyerap alternatif yang lebih murah diantaranya penggunaan biomassa tumbuhan dan limbah pertanian (Drake et al., 
1996).

Beberapa hasil penelitian yang telah dilaporkan yang menggunakan material biologi ataupun limbah pertanian sebagai material penyerap logam berat dari air limbah diantaranya, alga (Shengjun dan Holcombe, 1990), limbah apel (Maranon dan Sastre, 1991), sabut kelapa (Low et al., 1995), lumut (Low et al., 1997), sekam padi (Munaf dan Rahmiana, 1997), sargasssum (Fiquera et al., 1999), dan eceng gondok (Colleen et al., 1999).

Proses penyerapan ion logam oleh material biologi dipercaya melalui proses sorpsi yang melibatkan gugus fungsi yang berhubungan dengan protein, polisakarida gugus amino, karboksilat, hidroksil, sulfat, gugus sulfihidril, dan biopolimer lain yang ditemukan pada sel atau dinding sel yang berperan dalam mengikat logam (Greene, 1986). Berdasarkan hal tersebut di atas maka dilakukan penelitian dengan menggunakan biomaterial genjer sebagai penyerap logam kadmium $(\mathrm{Cd})$, dan tembaga $(\mathrm{Cu})$ dalam air limbah.

Eceng gondok telah digunakan untuk menyerap ion logam Eu (III) (Colleen et al., 1999). Untuk itu peneliti mencoba menggunakan tanaman genjer, yang mana genjer adalah salah satu tanaman air yang tumbuh liar dan sangat besar populasinya. Dimana sampai saat ini belum ada laporan tentang penggunaan genjer sebagai penyerap ion logam, maka dalam penelitian ini dicobakan menggunakan genjer untuk menyerap ion logam kadmium dan tembaga.

Penelitian ini bertujuan untuk mempelajari kondisi optimum penyerapan genjer terhadap ion kadmium $(\mathrm{Cd})$ dan tembaga $\mathrm{Cu}$ dengan menggunakan metoda dinamis. Kondisi optimum yang dipelajari adalah pengaruh $\mathrm{pH}$ larutan ion logam, ukuran partikel genjer, konsentrasi ion logam, dan suhu pemanasan genjer. Dari hasil kondisi optimum ini dapat diketahui efisiensi dan kapasitas penyerapannya terhadap ion logam tersebut.

Hasil penelitian ini diharapkan dapat memberikan informasi tentang pemanfaatan genjer sebagai salah satu bahan penyerap pengganti penyerap sintetis yang relatif mahal.

\section{METODOLOGI PENELITIAN}

\section{Alat dan Bahan}

Spektrofotometer serapan atom, neraca analitik, $\mathrm{pH}$ meter, oven listrik, pengayak, blender, kolom gelas, kertas saring, kapas, dan peralatan gelas.

Semua reagen yang digunakan mempunyai tingkat kemurnian yang tinggi keluaran Merck. Bahan yang digunakan dalam penelitian ini adalah $\mathrm{CdCl}_{2}, \mathrm{CuCl}_{2}, \mathrm{HNO}_{3}$, EDTA, $\quad \mathrm{NaH}_{2} \mathrm{PO}_{4}, \quad \mathrm{Na}_{2} \mathrm{HPO}_{4}, \quad \mathrm{C}_{6} \mathrm{H}_{5} \mathrm{O}_{7} \mathrm{H}_{3}$, $\mathrm{C}_{6} \mathrm{H}_{5} \mathrm{O}_{7} \mathrm{Na}_{3}, \mathrm{C}_{2} \mathrm{H}_{5} \mathrm{OH}$, dan aquadest.

\section{Preparasi sampel}

Sampel berupa tanaman genjer segar dicuci bersih kemudian dikeringanginkan selama beberapa hari. Kemudian sampel digiling dan diayak dengan ukuran partikel tertentu (150, 180, 250, dan $425 \mu \mathrm{m})$. Selanjutnya direndam dalam asam nitrat $0,1 \mathrm{~N}$ selama \pm 3 jam, lalu disaring dan dinetralkan, kemudian direndam dalam etanol $10 \%$ selama \pm 5 jam, dikeringanginkan kembali selama beberapa hari. Setelah itu material siap digunakan untuk perlakuan selanjutnya.

\section{Penentuan kondisi optimum penyerapan}

Untuk mengetahui efektifitas penyerapan ion logam kadmium dan tembaga oleh material genjer pada percobaan ini dilakukan dengan metoda dinamis (kolom). Variabel yang akan ditentukan adalah: $\mathrm{pH}$ larutan ion logam, ukuran partikel genjer, konsentrasi ion logam, dan suhu pemanasan genjer.

\section{Pengaruh pH larutan ion logam}

Sorben ditimbang sebanyak $0,5 \mathrm{~g}$ dengan ukuran partikel tertentu, dimasukkan ke dalam gelas piala dan ditambah dengan aquadest yang $\mathrm{pH}$-nya sama dengan $\mathrm{pH}$ larutan ion logam. Setelah diaduk lalu dimasukkan ke dalam kolom, selanjutnya dialirkan $10 \mathrm{~mL}$ larutan ion logam $10 \mathrm{mg} / \mathrm{L}$ yang telah diatur pH-nya 3, 4, 5, 6, dan 7. Effluent ditampung dan volumenya ditepatkan $10 \mathrm{~mL}$ dengan mengalirkan aquadest ke dalam kolom, kemudian diukur dengan spektrofotometer serapan atom (SSA).

\section{Pengaruh ukuran partikel genjer}

Sorben ditimbang sebanyak $0,5 \mathrm{~g}$ dengan ukuran partikel (150, 180, 250 dan 425 $\mu \mathrm{m})$, dimasukkan ke dalam beker dan ditambah aquadest $\mathrm{pH}$ optimum, kemudian dimasukkan ke dalam kolom. Larutan ion $10 \mathrm{mg} / \mathrm{L}$ dengan pH optimum dialirkan $10 \mathrm{~mL}$ ke dalam kolom. 
Effluent ditampung dan volumenya ditepatkan $10 \mathrm{~mL}$ dengan mengalirkan aquadest ke dalam kolom, kemudian diukur dengan spektrofotometer serapan atom (SSA).

\section{Pengaruh konsentrasi ion logam}

Sorben ditimbang masing-masing sebanyak $0,5 \mathrm{~g}$ dengan ukuran partikel optimum, dimasukkan ke dalam beker dan ditambah aquadest $\mathrm{pH}$ optimum, dimasukkan ke dalam kolom. Kemudian dialirkan larutan ion logam yang konsentrasinya divariasikan dengan $\mathrm{pH}$ optimum ke dalam kolom sebanyak $10 \mathrm{~mL}$. Effluent ditampung dan volumenya ditepatkan $10 \mathrm{~mL}$ dengan mengalirkan aquadest $\mathrm{pH}$ optimum ke dalam kolom, kemudian diukur dengan spektrofotometer serapan atom (SSA).

\section{Pengaruh suhu pemanasan}

Sorben ditimbang dengan ukuran partikel optimum, dipanaskan dengan variasi suhu $30,60,90,120$, dan $150{ }^{\circ} \mathrm{C}$ selama 30 menit, kemudian dimasukkan ke dalam desikator dan ditimbang masing-masingnya 0,5 $\mathrm{g}$, lalu dimasukkan ke dalam beker dan ditambah aquadest $\mathrm{pH}$ optimum, dimasukkan ke dalam kolom, selanjutnya dialirkan $10 \mathrm{~mL}$ larutan ion logam dengan konsentrasi optimum yang telah diatur $\mathrm{pH}$ nya sama dengan $\mathrm{pH}$ optimum. Effluent ditampung dan volumenya ditepatkan $10 \mathrm{~mL}$ dengan mengalirkan aquadest ke dalam kolom, kemudian diukur dengan spektrofotometer serapan atom (SSA).

\section{Elusi ion logam}

Ion-ion logam yang telah terserap dalam material genjer pada kondisi optimum dilepaskan kembali atau dielusi dengan cara mengalirkan $\mathrm{HNO}_{3}$ dan EDTA sebanyak 10 $\mathrm{mL}$. Selanjutnya konsentrasi ion logam ditentukan dengan spektrofotometer serapan atom (SSA)

\section{Aplikasi kondisi optimum penyerapan terhadap air limbah}

Air limbah disaring untuk memisahkan larutan dari partikel pengotor lainnya. Larutan diatur kondisinya sesuai dengan kondisi optimum yang telah diperoleh sebelumnya, dan kolom juga diperlakukan dengan kondisi optimum. Larutan limbah dialirkan ke dalam kolom, dan effluentnya ditampung dan volumenya ditepatkan $10 \mathrm{~mL}$ dengan mengalirkan aquadest $\mathrm{pH}$ optimum ke dalam kolom, kemudian diukur dengan spektrofotometer serapan atom (SSA)

\section{Pengolahan Data}

Untuk mengetahui efisiensi penyerapan $\mathrm{Cd}(\mathrm{II})$ dan $\mathrm{Cu}(\mathrm{II})$ oleh genjer, perhitugannya adalah:

$$
\mathrm{E}=\frac{C o-C e}{C o} \times 100 \%
$$

Sedangkan untuk mengetahui kapasitas serapan $\mathrm{Cd}$ (II) dan $\mathrm{Cu}$ (II) oleh genjer dihitung dengan menggunakan Persamaan Isoterm Langmuir, yang mana perhitungannya sebagai berikut:

$$
\frac{1}{Q}=\frac{K d 1}{Q m C}+\frac{1}{Q m}
$$

Dengan nilai $\mathrm{Q}=\frac{C o-C e}{m} x v$

Dimana;

$$
\begin{aligned}
& \mathrm{E}=\text { efisiensi penyerapan }(\%) \\
& \mathrm{Co}=\text { konsentrasi awal ion logam }(\mathrm{mg} / \mathrm{L}) \\
& \mathrm{Ce}=\text { konsentrasi akhir ion logam }(\mathrm{mg} / \mathrm{L}) \\
& \mathrm{Q}=\text { mg ion logam/g biomaterial } \\
& \mathrm{Kd}=\text { konstanta kesetimbangan ion logam } \\
& \mathrm{Qm}=\text { kapasitas serapan maksimum } \\
& \mathrm{M}=\text { massa biomaterial } \\
& \mathrm{V}=\text { volume ion logam }
\end{aligned}
$$

Karena Isoterm Langmuir plot 1/Q versus $1 / \mathrm{C}$ diperoleh garis linier. Dari persamaan linier $\mathrm{y}=\mathrm{bx}+\mathrm{a}$ maka nilai konstanta kesetimbangan (Kd) dan kapasitas serapan maksimum $(\mathrm{Qm})=$ 1/a dapat ditentukan.

\section{HASIL DAN PEMBAHASAN}

\section{Penentuan Kondisi Optimum Penyerapan}

Kondisi optimum penyerapan genjer yang telah ditentukan adalah pengaruh $\mathrm{pH}$ larutan ion logam, ukuran partikel genjer, dan suhu pemanasan. Penyerapan telah dilakukan dengan cara dinamis.

\section{Pengaruh pH larutan ion logam}

Kemampuan penyerapan suatu sorben dapat dipengaruhi oleh $\mathrm{pH}$ larutan. Hal ini berhubungan dengan protonasi atau deprotonasi permukaan sisi aktif dari sorben.

Pada Gambar1,terlihat bahwa penyerapan ion $\mathrm{Cd}$ (II) dan $\mathrm{Cu}$ (II) optimum pada $\mathrm{pH} 5$. 


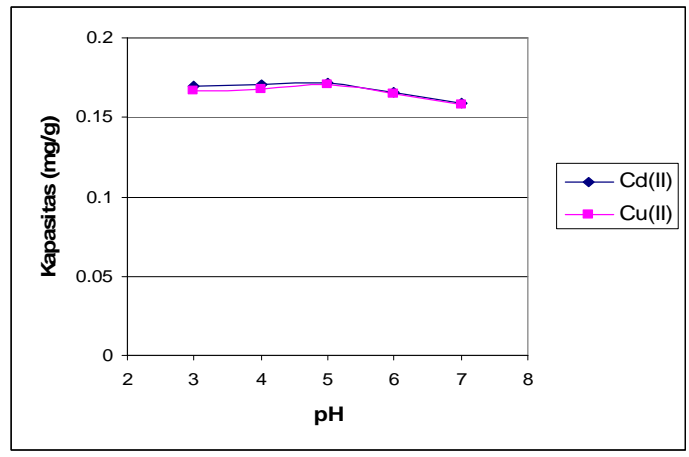

Gambar 1. Pengaruh $\mathrm{pH}$ terhadap penyerapan $\mathrm{Cd}(\mathrm{II})$ dan $\mathrm{Cu}(\mathrm{II})$ oleh genjer (ukuran partikel 180 $\mu \mathrm{m}$, volume $10 \mathrm{~mL}$, konsentrasi $10 \mathrm{mg} / \mathrm{L}$, massa sorben $0,5 \mathrm{~g}$ )

\section{Pengaruh ukuran partikel}

Ukuran partikel sorben berhubungan dengan luas permukaan yang dapat berinteraksi dengan dengan ion logam. Semakin kecil ukuran partikel semakin luas permukaannya sehingga kemampuan penyerapan terhadap ion logam juga akan meningkat.

Dari Gambar 2, terlihat bahwa penyerapan ion logam optimum pada ukuran partikel genjer $180 \mu \mathrm{m}$.

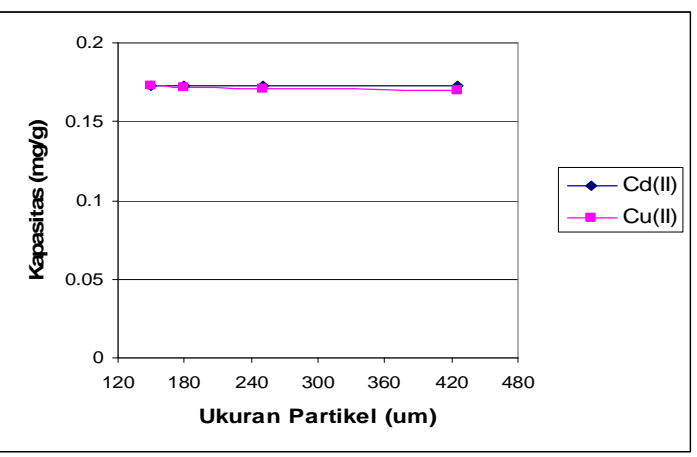

Gambar 2. Pengaruh ukuran partikel terhadap penyerapan $\mathrm{Cd}(\mathrm{II})$ dan $\mathrm{Cu}(\mathrm{II})$ oleh genjer $(\mathrm{pH} 5$, volume $10 \mathrm{~mL}$, konsentrasi $10 \mathrm{mg} / \mathrm{L}$, massa sorben $0,5 \mathrm{~g})$

\section{Pengaruh konsentrasi ion logam}

Konsentrasi ion logam berhubungan dengan jumlah sisi aktif yang terdapat pada permukaan sorben,bila jumlah sisi aktif cukup besar disbanding jumlah ion logam, maka kapasitas penyerapan akan tinggi sampai pada saat jumlah sisi aktif sama dengan jumlah ion logam, maka kapasitas penyerapannya akan menurun.

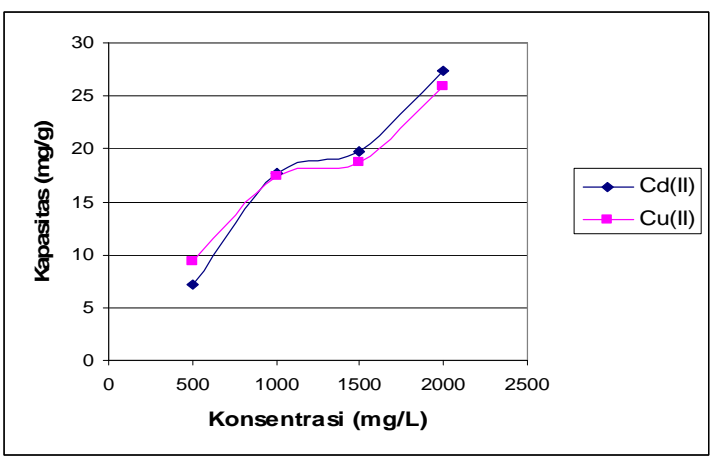

Gambar 3. Pengaruh konsentrasi larutan terhadap penyerapan $\mathrm{Cd}(\mathrm{II})$ dan $\mathrm{Cu}(\mathrm{II})$ oleh genjer $(\mathrm{pH} 5$, ukuran partikel $180 \mu \mathrm{m}$, volume $10 \mathrm{~mL}$,massa sorben $0,5 \mathrm{~g}$ )

\section{Pengaruh suhu pemanasan}

Pemanasan sorben dapat meningkatkan kemampuan penyerapannya. Pemanasan yang dilakukan dapat memperbesar pori-pori sorben sehingga akan meningkatkan penyerapan, tetapi kadang-kadang kemampuan penyerapan sorben tidak dipengaruhi oleh pemanasan.

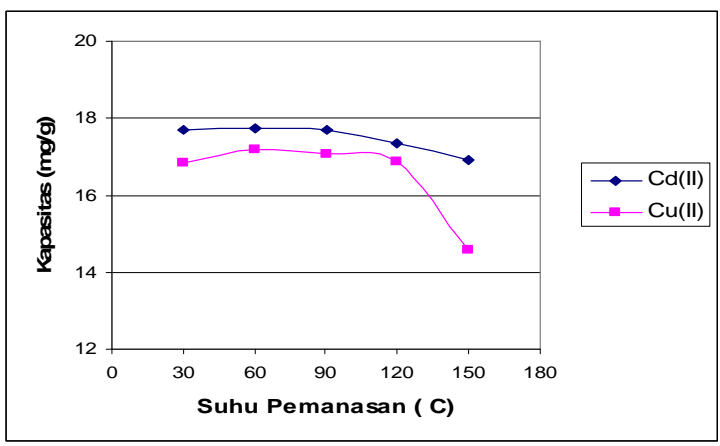

Gambar 4. Pengaruh suhu pemanasan terhadap

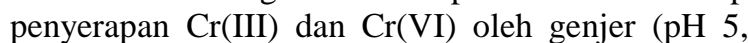
ukuran partikel $180 \mu \mathrm{m}$, volume $10 \mathrm{~mL}$, konsentrasi $8 \mathrm{mg} / \mathrm{L}$, massa sorben $0,5 \mathrm{~g}$ )

Pada Gambar 4, terlihat bahwa pemanasan yang dilakukan terhadap sorben sampai suhu $150 \quad{ }^{\circ} \mathrm{C}$ tidak memberikan pengaruh yang berarti terhadap kemampuan penyerapannya. Sehingga dalam percobaan selanjutnya untuk $\mathrm{Cd}$ (II) dan $\mathrm{Cu}$ (II) digunakan sorben genjer tanpa pemanasan.

Pada suhu $150 \quad{ }^{\circ} \mathrm{C}$ terlihat bahwa kapasitas penyerapannya semakin menurun, hal ini disebabkan karena telah terjadi kerusakan struktur kimia dari genjer.

\section{Elusi ion logam}

Ion logam yang telah diserap oleh genjer dielusi dengan menggunakan asam nitrat $0,5 \mathrm{M}$. Pada tabel 1 , terlihat nilai rekoverinya 
relative kecil, ini menunjukkan bahwa ion logam yang terserap oleh genjer terikat dengan kuat sehingga tidak mudah untuk dilepaskan kembali. Hal ini menyatakan bahwa asam nitrat yang digunakan sebagai eluen tidak sesuai untuk mengelusi ion logam dari sorben genjer. Maka dicoba menggunakan EDTA 0,1 M (garam EDTA), karena EDTA merupakan kompleksan atau senyawa pembentuk komplek dengan ion logam. Ternyata dengan EDTA efisiensinya relative kecil, hal ini disebabkan karena $\mathrm{pH}$ perlakuan tidak sesuai untuk membentuk komplek dengan EDTA.

Tabel 1. Rekoveri untuk ion $\mathrm{Cd}(\mathrm{II})$, dan $\mathrm{Cu}(\mathrm{II})$ menggunakan $\mathrm{HNO}_{3}$ dan EDTA sebagai eluen.

\begin{tabular}{|c|c|c|}
\hline \multirow{2}{*}{ Eluen } & \multicolumn{2}{|c|}{ Recovery (\%) } \\
\cline { 2 - 3 } & $\mathbf{C d ( I I )}$ & $\mathbf{C u}(\mathbf{I I})$ \\
\hline $\mathrm{HNO}_{3}$ & 100 & 67,84 \\
\hline EDTA & 99,82 & 63,44 \\
\hline
\end{tabular}

\section{Aplikasi kondisi optimum penyerapan terhaadap air limbah}

Untuk mengaplikasikan penggunaan genjer sebagai biosorben terhadap $\mathrm{Cd}(\mathrm{II})$ dan $\mathrm{Cu}(\mathrm{II})$ dicobakan terhadap air limbah laboratorium kimia. Pada tabel 2, dapat dilihat efisiensi penyerapan genjer terhadap ion logam tersebut terhadap air limbah adalah 62,41-100 $\%$.

Tabel 2. Hasil penyerapan ion logam pada air limbah oleh genjer.

\begin{tabular}{|c|c|c|}
\hline Ion logam & $C d(I I)$ & $C u(I I)$ \\
\hline $\begin{array}{c}\text { Konsentrasi awal } \\
(\mathrm{mg} / \mathrm{L})\end{array}$ & 1,486 & 1,010 \\
\hline $\begin{array}{c}\text { Konsentrasi akhir } \\
(\mathrm{mg} / \mathrm{L})\end{array}$ & 0,000 & 0,3796 \\
\hline $\begin{array}{c}\text { Efisiensi penyerapan } \\
(\%)\end{array}$ & 100 & 62,41 \\
\hline Kapasitas (mg/g) & 0,0297 & 0,0126 \\
\hline
\end{tabular}

Dari hasil penyerapan genjer terhadap air limbah memberikan efisiensi penyerapan yang cukup baik sehingga genjer ini dapat digunakan sebagai biosorben alternatif.

\section{KESIMPULAN}

Dari penelitian yang telah dilakukan terhadap penyerapan ion logam kromium oleh genjer (limnocharis flava) menggunakan sistem dinamis, dapat disimpulkan:
1. Kondisi optimum penyerapan ion logam oleh sorben genjer dapat dilakukan pada $\mathrm{pH}$ larutan ion logam 5, ukuran partikel 180 $\mu \mathrm{m}$, dan tanpa pemanasan.

2. Kapasitas penyerapan genjer terhadap ion logam kadmium dan tembaga masingmasing adalah 17,71 dan $17,45 \mathrm{mg}$ ion logam/g sorben.

3. Jumlah ion logam logam kadmium dan tembaga yang dielusi dengan $\mathrm{HNO}_{3}$ dan EDTA diperoleh kembali sebanyak 63,44$100 \%$

4. Kapasitas penyerapan genjer terhadap ion logam kadmium dan tembaga dari air limbah laboratorium masing-masing adalah 0,030 dan $0,013 \mathrm{mg}$ ion logam/g sorben.

\section{UCAPAN TERIMA KASIH}

Pada kesempatan ini penulis mengucapkan terima kasih kepada Bapak Prof. Dr. Edison Munaf, M.Eng, dan Ibu Dr. Rahmiana Zein, atas segala masukan dan sarannya, pimpinan dan staff Laboratorium Kimia Lingkungan Jurusan Kimia FMIPA Universitas Andalas atas semua sarana dan prasarana, dan teman-teman S1 dan S2 Jurusan Kimia FMIPA Universitas Andalas atas segala do'a dan dukungannya.

\section{DAFTAR PUSTAKA}

1. Colleen, K., R.E. Mielke., D. Dimaquibo., A.J. Curtis., and J.G. Dewitt. 1999. Adsorption of Eu (III) onto Roots of Water Hyacinth. J. Environ.Sci. Technol. 33 : 1439-1443.

2. Drake, L.R., and G.D. Rayson. 1996. PlantDerived Materials for metal ion-Selective Binding and Preconcentration. Anal. Chem.News \& Features. 22-27.

3. Fiqueira, M.M., B.Volesky and H.J. Mathieu. 1999. Instrumental Analysis Study of Ion Species biosorption by Sargassum Biomass. Environ. Sci. Technol. $33: 1840-1846$.

4. Fourest, E., and J.C. Roux. 1992. Heavy Metals Biosorption by Fungal Mycelial byProducts : Mechanism and Influence of $\mathrm{pH}$. Appl. Microbiol Biotechnol. 37 : 399-403.

5. Giequel, 1., D. Wolbert and A. Laplanche. 1997. Adsorption of Atrazine by Powdered Activated Carbon : Influence of Dissolved Organic and Mineral Matter of Natural Water. Environ. Sci. Technol. 18 : 467-478. 
6. Greene, B., M. Hosea., R. McPherson., M. Henzl., M.D. Alexander., and D.W. Darnall. 1986. Interaction of Gold (I) and (III) Complexes with Alga Biomass. Environ. Sci. Technol. 20 : 627-631.

7. Greenberg, E.A. 1992. Standard Methods for the Examination of Water and Waste Water. $18^{\text {th }}$ ed, American Public Health Association. Washington. 29-30.

8. Guibal, E., C. Roulph., and P.Le Cloirec. 1992. Uranium Biosorption by A Fillamentous Fungus mucor michei: $\mathrm{pH}$ Effect on Mechanisms and Performances of Uptake. Water. Env. Research. 8: 11391145.

9.Lessi, P., N.L. Diaz F., J.C. Moreira and Joaquim J.T.S.Campos. 1996. Sorption and Preconcentration of Metal Ions on Silica Gel Modified UIT 2,5-Dimercapto-1,3,4Thiadiazolc. Anal.Chim.Acta. 327 : 183190.

10. Low, K.S., C.K. Lee. And S.G. Tan. 1995. Effect of Dye Modification on the Sorption of Copper by Coconut Husk. J. Environ. Tech. $16: 877-883$.

11. Low, K.S., C.K. Lee. And S.G. Tan. 1997. Sorption of Trivalent Chromium from Tannery Waste by Moss. J. Environ. Tech. $18: 449-454$.

12. Matheichal, T.T., and Qiming Yu. 1999. Biosorption of Lead (II) and Copper (II) from Aqueous Solutions by Pre-Treated Biomass of Australian Marine Algae. Bioresource, Technol. 69 : 223-327.

13. Manahan, S.E. 1984. Environmental Chemistry. 4 th. Brook and Cole Publ., California.

14. Maranon, E., and H. Saetre. 1991. Heavy Metal Removal in Packed Bed Using Apple Waste. Anal. Chem. 64 : 39-44.

15. Michael, G., and Pierre Apriou.1994. Three-Column System for Preconcentration and Speciation Determination of trace
Metals in Natural Waters. Anal.Chim.Acta. 297 : 369-376.

16. Munaf, E., and R. Zein. 1997. The Use of Rice Husk for Removal Toxic Metals from Waste Water. J. Environ. Tech. 18 : 359362.

17. Palar, H. 1994. Pencemaran dan Toksikologi Logam Berat. Rineka Cipta. Jakarta. 133-139.

18. Shengjun, M., Holcombe J.A. 1990. Preconcentration of Copper on Algae and Determination By Slurry Furnace Atomic Absorption Spectrometry. Anal. Chem. 62 : 1994-1997. 